\title{
Intertidal life: field observations on the clingfish Gobiesox barbatulus in southeastern Brazil
}

\author{
Tiago H. S. Pires ${ }^{1}$ and Fernando Z. Gibran ${ }^{2}$
}

The clingfish Gobiesox barbatulus shows nocturnal feeding activity, spending most part of the day stationary and adhered to the inferior part of stones. To feed, this species uses the sit-and-wait and particulate feeding tactics. It shows a carnivorous feeding habit mostly consuming small benthic crustaceans. It can move in two ways: (1) "stone-by-stone", sliding its ventral sucker disc across each stone and (2) "surf", when it takes advantage of the energy of the ebbing tide to quickly cross a distance up to four times its body length. Its reproductive season occurs between the end of spring and the beginning of summer, during which time it lays about 2,000 adhesive eggs of $1 \mathrm{~mm}$ each in a single layer under stones. It has more than one egg-laying session per reproductive season, therefore showing several different developmental stages. It performs fanning, mouthing and guarding of the eggs as forms of parental care. Data shown here also indicates that G. barbatulus has some shelter fidelity, being probably territorial.

O peixe-pregador Gobiesox barbatulus apresenta atividade alimentar noturna, permanecendo estacionário e aderido à parte inferior de pedras durante a maior parte do dia. Para se alimentar utiliza as táticas de espreita e consumo de material particulado. Apresenta hábito alimentar carnívoro e ingere principalmente crustáceos bentônicos. Locomove-se principalmente de duas formas: (1) "pedra-a-pedra", deslizando seu disco adesivo ventral por sobre pedras adjacentes e (2) "surfe", quando se aproveita da energia da maré vazante para percorrer rapidamente distâncias de até quatro vezes seu tamanho. A época reprodutiva desta espécie ocorre entre o final da primavera e início do verão, quando deposita aproximadamente 2.000 ovos adesivos de 1 $\mathrm{mm}$ de diâmetro cada e dispostos em uma única camada na parte inferior de pedras. Possui mais de uma desova por estação reprodutiva e, portanto, contendo ovos em diferentes estágios de desenvolvimento. Realiza ventilação, limpeza e guarda dos ovos como formas de cuidado parental. Os dados aqui apresentados também indicam que G. barbatulus possui certa fidelidade aos locais nos quais se abriga, sendo provavelmente uma espécie territorial.

Key words: Activity, Microhabitat, Diet, Reproduction, Gobiesocidae.

\section{Introduction}

The intertidal fishes (i.e., fishes that spend their whole postlarvae period of life in this region; $c f$. Gibson, 1969) are generally small, territorial, with negative buoyancy and a short life span-traits that reduce their dispersal potential and increase their probability of speciation. These features make them interesting objects for studies on ecology and evolution (Prochazka et al., 1999). However, field observations on intertidal fishes are relatively rare, and the fish fauna associated with tropical tidal habitats are poorly known (Chotkowski, 1999). As pointed out by Coleman (1999: 178): "More researchers need to get in the water (and) turn over rocks in the intertidal zone to observe these animals in the wild (...)".
Gobiesocidae includes some typical examples of intertidal fishes (Chotkowski, 1999). This group includes about 140 benthic fish species in 36 genera occurring in all major oceans and also in freshwater habitats (Nelson, 2006). They do not possess a swim bladder and are known as clingfishes, due to their thoracic sucking disc, which is formed by modified pelvic fins and skin folds (Johnson \& Greenfield, 1983; Nelson, 2006). Six species of clingfishes are found in Brazilian waters (Sampaio et al., 2004).

Hofrichter \& Patzner (2000) studying seven Mediterranean Gobiesocidae species reported that one of the studied species is closely adapted to pebbles and boulders. Our preliminary observations revealed that the lappetlip clingfish Gobiesox barbatulus Starks, 1913 is a common species in tide pools and cobblestone fields located in a small protected area within

\footnotetext{
${ }^{1}$ Instituto Nacional de Pesquisas da Amazônia, Coordenação de Pesquisas em Biologia Aquática, Cx. Postal 478, 69011-970 Manaus, AM, Brazil.thspires@gmail.com

${ }^{2}$ Centro de Biologia Marinha da Universidade de São Paulo (CEBIMar-USP). Rodovia Manoel Hipólito do Rego, Km 131.5, 11600-000 São Sebastião, SP, Brazil. Current address: Universidade Federal do ABC (UFABC), Centro de Ciências Naturais e Humanas (CCNH). Rua Santa Adélia, 166, Bairro Bangu, 09210-170 Santo André, SP, Brazil. fernando.gibran@ufabc.edu.br
} 
the continental margin of the São Sebastião Channel, in southeastern Brazil. Based on these preliminary data and literature data we supposed that this type of habitat might be important for other Gobiesocidae as well, including $G$. barbatulus. The aim of the present study was to investigate the activity, the microhabitat use, and the feeding behavior of the lappetlip clingfish. We also gathered information about the mating behavior, egg characteristics, parental care, and general diet of this species.

\section{Material and Methods}

Study area. Field work was carried out in the São Sebastião Channel, from February 2006 to February 2007 (13 monthly trips, with duration of four to 13 days each). This stretch 25 $\mathrm{km}$ long on the coast of São Paulo, located in southeastern Brazil ( $23^{\circ} 41^{\prime}$ to $23^{\circ} 54^{\prime}$ 'S and $45^{\circ} 19^{\prime}$ 'to $45^{\circ} 30^{\prime} \mathrm{W}$ ), includes rocky shores and rocky reefs as well as sandy and muddy beaches (Fig. 1). The study area contains pebbles $(0.4-6.4 \mathrm{~cm})$, cobblestones $(6.4-25.6 \mathrm{~cm})$ and boulders $(>25.6 \mathrm{~cm})$. During the study, water surface temperatures varied from 17.5 to $29.0^{\circ} \mathrm{C}$ (average $23.0^{\circ} \mathrm{C}$ ) and horizontal visibility was between 0.3 and $5.0 \mathrm{~m}$ (average $1.8 \mathrm{~m}$ ).

Pebble field at the Baleeiro Isthmus (area "a" in Fig. 1). This area is composed mostly of boulders and pebbles. It was scanned during the whole study period. A portable PVC square frame of $1 \mathrm{~m}^{2}$ was used as a sample unit. In this area, and during each sampling session, it was possible to register the exact position of each clingfish found using three conspicuous stones as natural reference points. These data allowed for further observations at the same spot, aiming to check shelter fidelity and also to observe which activities the fish performed during the 24-h cycle and at different tide levels.

Pebble, cobblestone, and boulder field of Saco Grande (area "b" in Fig. 1). This area is comprised of many stones with diameters greater than $1 \mathrm{~m}$. Only microhabitat preferences and behavior were investigated in this region.

Other areas. Searches for clingfishes and complementary observations were also performed in other areas of the São Sebastião Channel. Individuals of $G$. barbatulus were also found

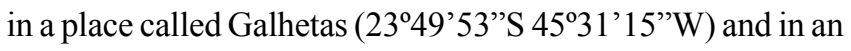
area located between Ponta Itapuã and Ponta da Questão $\left(23^{\circ} 49^{\prime} 22^{\prime \prime} \mathrm{S} 45^{\circ} 28^{\prime} 16^{\prime \prime} \mathrm{W}\right)$. Many other areas along the continental margin of this channel were also scanned, but no clingfishes were found (e.g., the areas "c" and "d" in Fig. 1).

Field-work. Underwater observations (using ad libitum and focal animal samplings; Altmann, 1974) and collection of specimens were undertaken during 103 (70 diurnal, 23 crepuscular and 10 nocturnal) hours of snorkelling, in depths of up to $3 \mathrm{~m}$ (mostly less than $0.5 \mathrm{~m}$ ). For each observation session, we recorded: the number of individuals found; their size (total length, TL, measured with a plastic ruler of $1 \mathrm{~mm}$ of precision); their orientation related to the shelter entrance and water flux; the depth at which they were found; the presence of other animals near the hiding places; three descriptive environmental variables (water temperature, transparency, and type of bottom); and the five characteristic of the pebbles, cobblestones and boulders as follows (stone characteristics are modified from Hofrichter \& Patzner, 2000):

a) Size: $<5,5-15,15-30,30-50$ or $>50 \mathrm{~cm}$.

b) Surface aspect: smooth, intermediate or rough.

c) General form: rounded, irregular, flatted or rectangular.

d) Main coloration: white, grey, darkened or red.

e) Aufwuchs: absent, little, medium, much or totally covered (i.e., full).

The type of substratum in which each "shelter-stone" was on (e.g., smaller stones, bigger stones, sand etc.), and the three dimensions of each one of the "shelter-stone" were also recorded. There was only one case in which an individual was not under a rounded stone, but inside a rock crevice. After the observation sessions, the clingfishes were collected manually, or with the help of hand nets or transparent plastic bags. Fifty three individuals were measured in the same spot where they were attached and 11 were anesthetized with clove oil and then fixed in formalin for diet analysis. The individuals used for diet were collected at the end of the trips, after the behavioral observations.

Data gathered at Baleeiro Isthmus and Saco Grande (areas "a" and "b" in Fig. 1) were statistically analysed for comparisons and also used to draw a histogram (Fig. 2). During night and twilight observations, to reduce the disturbance caused by the white-light, we used a dive light coupled with a red filter (cf. Helfman, 1983). On 16 occasions the fish were found during daylight hours, but the behavioral observations were sometimes extended to twilight and night hours.

Diet analysis. Stomach content analysis was performed only for 11 individuals. Voucher specimens were deposited in the fish collection of the Laboratório de Ictiologia de Ribeirão Preto (LIRP), Departamento de Biologia (FFCLRP), Universidade de São Paulo, in Ribeirão Preto, Brazil (LIRP 5954). For each broad category of food item, the frequency of occurrence (Bowen, 1992) and the percent composition (Hynes, 1950) were calculated, allowing a rapid identification of this specie's feeding habits.

Egg counts. Data about the size and the amount of eggs were recorded in February 2006. For the two other records (November and December 2006) the amount was only estimated using two size dimensions and assuming that the eggs were of the same size and the egg layer was spherical.

\section{Results}

Habitat and microhabitat use. Gobiesox barbatulus individuals were found only at places comprised of pebbles, cobblestones and boulders. 


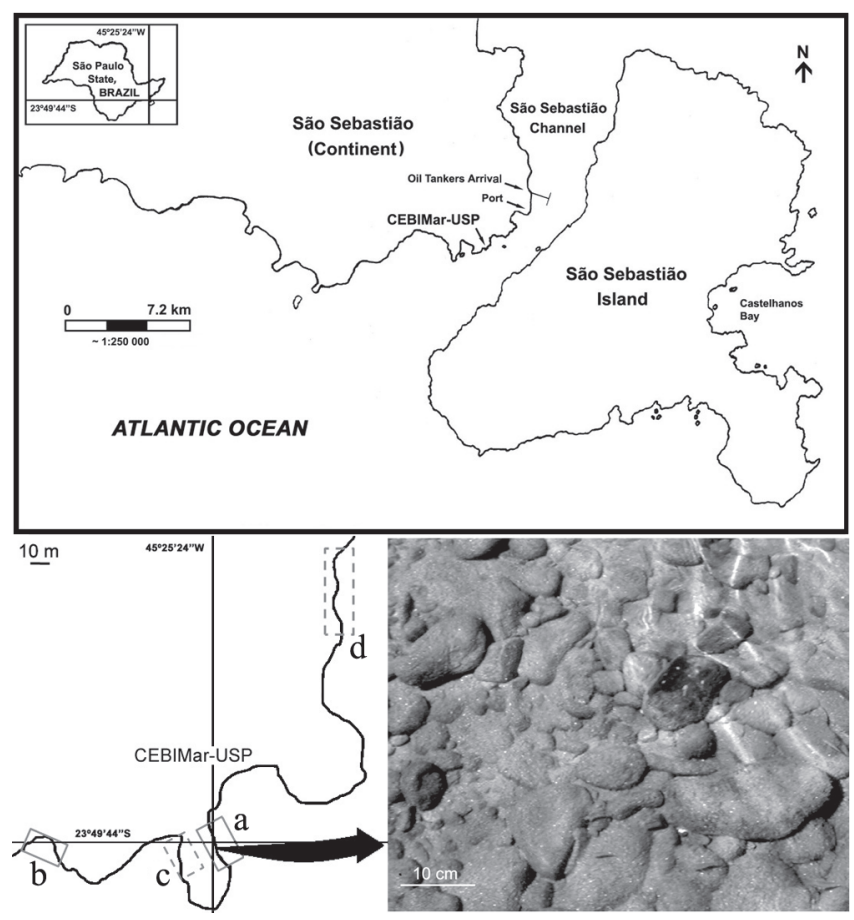

Fig. 1. Map indicating the location of the study area (São Sebastião Channel) on the coast of São Paulo, southeastern Brazil, and the scanned regions into the marine protected area of CEBIMar-USP (the marine station of the University of São Paulo): (a) pebbles field at the Baleeiro Isthmus; (b) pebbles, cobblestones and boulder field of Saco Grande; (c, d) examples of other scanned regions at the continental margin of the São Sebastião Channel with pebbles and/or tide pools. The big black arrow shows a detail of the Gobiesox barbatulus habitat at the intertidal zone.

In the two most scanned areas (Baleeiro Isthmus and Saco Grande; areas "a" and "b" in Fig. 1), a large amount of individuals was seen adhered underneath stones between $15-30 \mathrm{~cm}$ long with smooth surfaces, rounded, and without aufwuchs (Fig. 2). The only difference among these two regions in the data acquired was the colour of the "shelterstone" used by the fish (Table 1). In the region of Saco Grande, where a larger abundance of white stones was observed, the clingfishes were more often adhered to these stones, while in the Baleeiro Isthmus, where a larger abundance of dark stones was observed, the clingfishes were more often adhered to these dark stones (Fig. 2).

Feeding activity and behavior. All individuals observed during the day were stationary, oriented dorsal side down, and adhered underneath stones. They initiated feeding activity during the evening twilight, performing a series of short and long interval movements that grow both in complexity and frequency with time. All individuals observed during the night were active and feeding.

It is common for G. barbatulus to get out of the shelters to search for other feeding places when the waterline approaches the shelters. Some standard movements are performed before
Table 1. Chi-square tests $\left(\chi^{2}\right)$ for analyses on microhabitat preference between the two most well scanned areas (Baleeiro Isthmus and Saco Grande). The characteristic in bold type was the only statistically significant and, thus, different between these areas

\begin{tabular}{lccc}
\hline "Shelter-stone" characteristics & $\chi^{2}$ & d.f. & $P$ \\
\hline Size & 0.50 & 4.00 & 0.97 \\
Surface aspect & 5.40 & 2.00 & 0.06 \\
General form & 4.90 & 3.00 & 0.17 \\
Main coloration & $\mathbf{2 9 . 4 0}$ & $\mathbf{3 . 0 0}$ & $<\mathbf{0 . 0 0 1}$ \\
Aufwuchs cover & 4.80 & 4.00 & 0.30 \\
\hline
\end{tabular}

their departure. They can: (1) make a round over the whole "shelter-stone" surface (Fig. 3a sequence 1 to 8) and/or (2) rotate their bodies, as a roll movement (see Alexander, 1967) (Fig. 3b).

An atypical behavior occurred in January 2007, when strong breakers occurred at the study site. In this particular situation, two individuals were active during the day. In many occasions they were totally or partially covered by sediments, as well as their "shelter-stones", until the waves washed out the sediments. After such perturbation they temporarily left their original "shelter-stones" to attach to adjacent stones before quickly coming back to be covered again. This behavior was repeated many times until the fish finally reached a deeper region with smaller amounts of suspended sediments. No attempt of the fish to actively uncover themselves was observed.

At night, the clingfishes left their "shelter-stones" in one of the following two modes, here denominated as "stone-bystone" and "surf". In "stone-by-stone", the fish moves by sliding its ventral disc among adjacent stones, allowing quick adherence when any disturbance occurs (e.g., water flux from waves). In "surf", the fish uses the wave energy from the ebbing tide to move; once in a vertical position it detaches itself from a stone, and then with a quick $180^{\circ}$ body rotation, it crosses a distance of up to $20 \mathrm{~cm}$. The movement ends with the adherence on another adjacent stone. It is important to note that the clingfishes are not good swimmers.

After leaving their hiding places, the clingfishes performed sit-and-wait predation (see Sazima, 1986) and particulate feeding (see Keenleyside, 1979). When the prey approaches them, the clingfishes make a quick movement to capture it, moving the head laterally and/or moving the whole body forward, always keeping the ventral disc in contact with the stone. Clingfishes' bites were mostly directed to clouds of mysidaceans.

Diet. The studied clingfish fed mainly on small benthic (Amphipoda and Copepoda Harpacticoida) or planktonic (Mysidacea and Ostracoda) crustaceans. This prey type was present in 10 of the 11 stomachs analyzed. The only individual without this food item had $70 \mathrm{~mm}$ TL and its stomach was filled by one G. barbatulus individual of $20 \mathrm{~mm}$ TL (Table 2; Fig. 4).

Eggs and reproduction. Three nests with eggs were found in February, November, and December $2006(2,000 ; 1,300$; and 2,500 eggs, respectively), which corresponds to the end of spring and 
the beginning of summer. The eggs were spherical, yellow, with $1 \mathrm{~mm}$ diameter, and were laid under stones in a single layer, composed of eggs at different developmental stages (Fig. 5).

In general, an adult individual was close to the eggs displaying parental behavior (i.e., care and protection of eggs) in the forms of guarding, fanning and mouthing. Fanning was performed with the pectoral fins. In one occasion, these behaviors were video recorded. Parental behavior was observed during the day and night and, thus, we presume that clingfish can perform this behavior through the whole 24-h cycle. The adult caring for the eggs never abandoned the nest and fed only using the particulate feeding tactic while continuously protecting the eggs. This individual also did not leave the nest even when completely emerged. However, the clingfish remained in this situation for a very short time (e.g., about $5 \mathrm{sec}$, between waves). It was not possible to identify the sex of the individual performing parental behavior (see Discussion).

In one occasion, during the day, two individuals of different sizes ( 50 and $30 \mathrm{~mm} \mathrm{TL}$ ) were adhered to the same stone and displaying courtship behavior. We observed no typical sequence of movements leading to mating, but we believe that the positions preceding mating deserve special attention (these positions are described as follows and illustrated in Fig. 6). Just before mating the individuals adopted one of three peculiar positions: (1) opposite to each other (Fig. 6a); (2) "X" form (Fig. 6e); or (3) side-by-side (Fig. 6h). We called these positions as "pre-mating" and observed that the contact held by this position can act as a final stimulus to mating. Additionally, we observed that the approach could be made by both male and female, but it was always done in a slowly manner. Once in contact to each other, the individuals quivered their bodies, presumably mating. The couple did not remain together (Fig. 6b or 6f), and the larger individual often performed parental behavior immediately after mating (Fig. 6b). Following parental care, the larger individual moved to a spot without eggs under the stone (e.g., Fig. 6c), the individuals approached each other again (Fig. 6c, d, g), and the movements were repeated several times for about $90 \mathrm{~min}$ until dusk, when the smaller individual left the nest.

The individual performing parental behavior kept its caudal and dorsal fins expanded, allowing the posterior part of the body to swing with the water movements, a posture never saw during this study for a G. barbatulus individual away from a nest.

Site fidelity. Fifteen individuals remained nearby where they were first observed (i.e., in the same or adjacent stone) for two consecutive days, and eight individuals for three consecutive days (individuals were isolated in space and time, which made it possible to identify individuals by their TL, six of them had very different sizes, about 30 or $60 \mathrm{~mm}$ ).

\section{Discussion}

Habitat, microhabitat use, feeding activity, and behavior. Gobiesox barbatulus inhabits shallow intertidal areas composed of pebbles, cobblestones and/or boulders, which is in accordance with the literature on the importance of such habitats for clingfishes (Hofrichter \& Patzner, 2000). This is an evening twilight-nocturnal and slow-swimming fish that feeds on prey available within the near vicinity of its hiding places, and it stays stationary and adhered under rounded stones during the day.

Probably their capacity to change general body colour (becoming darker, brighter, or exhibiting a disruptive pattern) allows them to be camouflaged against their shelter. The body colours for most clingfish species vary and show a close relationship with their habitats (Hofrichter \& Patzner, 2000). In contrast to the pelagic forms, the benthic fishes

\section{Microhabitat Use}

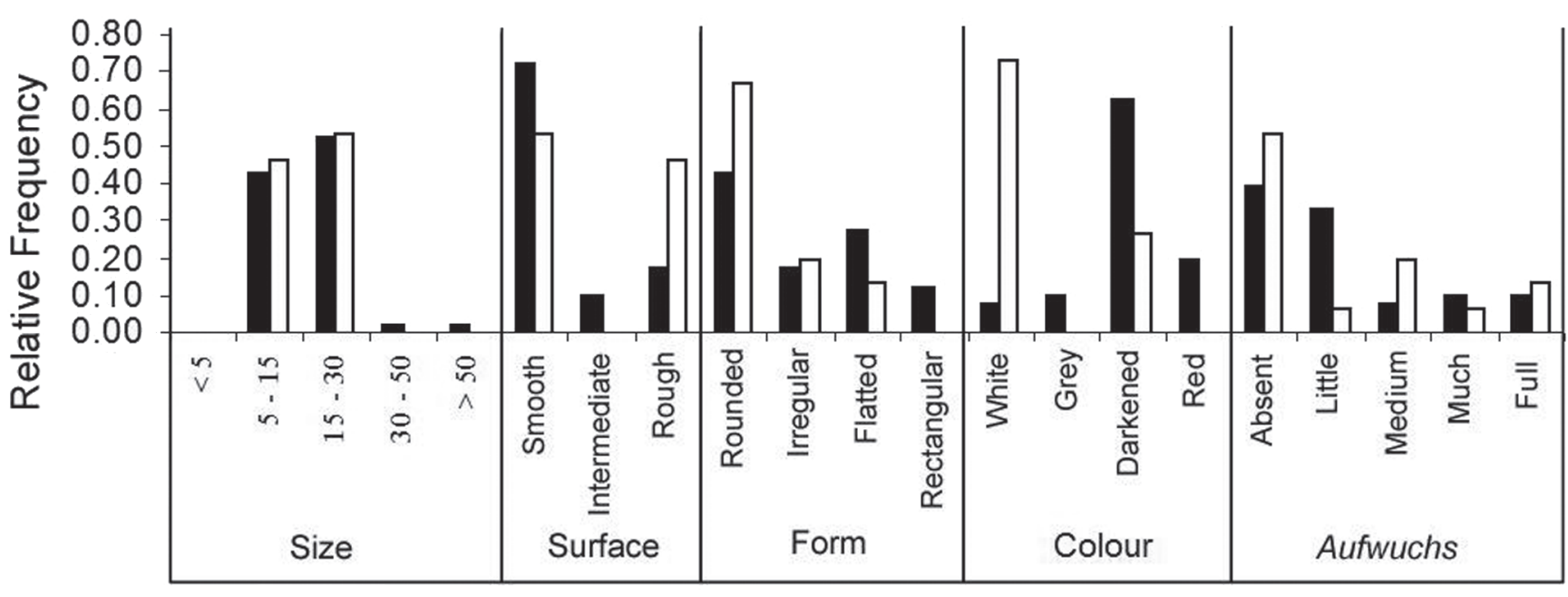

Stone Characteristics

- Baleeiro Isthmus $\square$ Saco Grande

Fig. 2. Microhabitat use by Gobiesox barbatulus in the Baleeiro Isthmus $(\mathrm{n}=51) v$ s. Saco Grande $(\mathrm{n}=13)$. Size in $\mathrm{cm}$. 

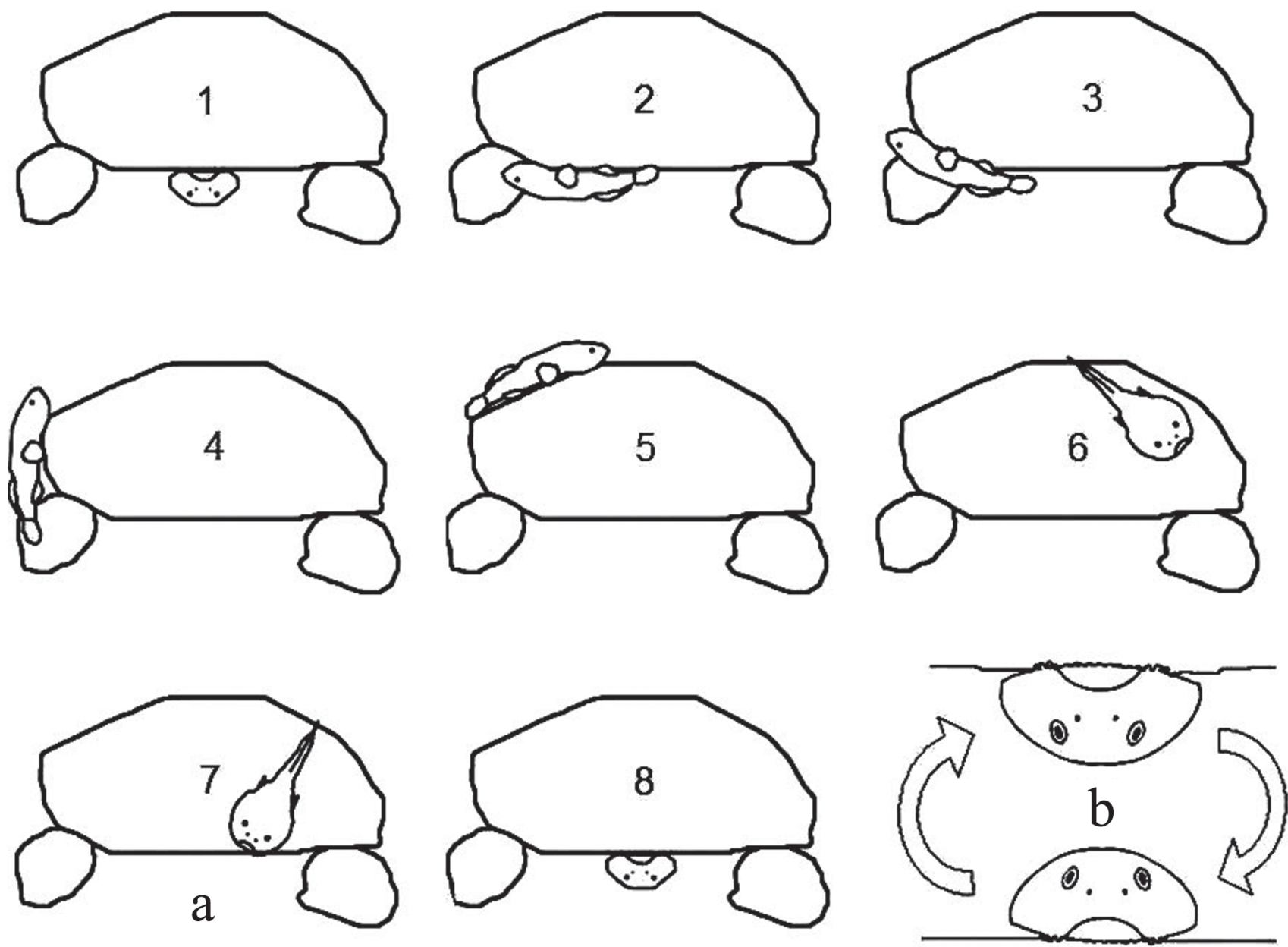

Fig. 3. Standard movements performed by Gobiesox barbatulus before leaving the "shelter-stone": (a) sequence 1-8 illustrates a round over the "shelter-stone"; (b) body rotation under the "shelter-stone".

(in a broad sense) have a higher capacity to change their general body colour (Gibson, 1969).

The microhabitat preferences of G. barbatulus are very similar to those of the blunt-snouted clingfish Gouania willdenowi (Hofrichter \& Patzner, 2000). This similarity is likely to be related to the fact that both species inhabit the shallowest intertidal zone, migrating near the waterline when the tide goes down. Such a zone normally contains a great amount of rounded, smooth and bare (i.e., without aufwuchs) stones. The only difference of microhabitat preferences among these two species would be the preference of $G$. willdenowi to smaller stones (maybe due to its smaller body size; see Froese \& Pauly, 2008), whereas G. barbatulus seems to prefer relatively larger stones (present study).

Diet. Stomach content analyses showed that G. barbatulus is a carnivorous species that feeds on crustacean. This type of prey represents the main food item in the diet of rocky intertidal inhabitants (e.g., Bennett et al., 1983; Grossman, 1986; Varas \& Ojeda, 1990; Norton \& Cook, 1999). The vegetal debris found among stomach contents are probably unintentionally swallowed together with prey, since this species' habitat becomes frequently full of particulate algae lifted by the waves. Cannibalism was observed here and is commonly reported in the literature on intertidal fishes. It was reported for other species of the same genus (see Johnson, 1970); thus, these data indicate that the Gobiesox species are opportunistic feeders.

Eggs, reproduction and site fidelity. Reproduction during the spring and summer is probably related to a larger food availability for the offspring during these seasons, which is a rule for most living organisms (Bye, 1984) and fishes that lay eggs in the intertidal zone are not an exception (Gibson, 1969).

Table 2. Frequency of occurrence (\%) of food items found in stomach contents of Gobiesox barbatulus (20-70 mm TL; $\mathrm{n}=11)$.

\begin{tabular}{lc}
\hline \multicolumn{1}{c}{ Food items } & Frequency of occurrence \\
\hline Crustacea & 91 \\
Amphipoda & 27 \\
Copepoda (Harpacticoida) & 27 \\
Mysidacea & 18 \\
Ostracoda & 9 \\
Unidentified crustaceans & 9 \\
Unidentified organic material & 91 \\
Vegetal debris & 54 \\
Teleostei (small G. barbatulus) & 9
\end{tabular}




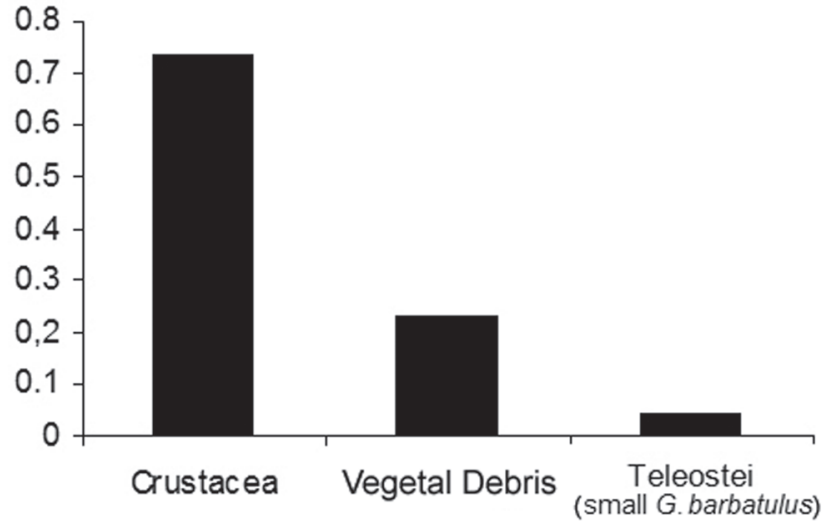

a

Fig. 4. Percent composition of food items found in stomachs of 11 Gobiesox barbatulus individuals: (a) broad taxonomic categories; (b) only crustaceans and unidentified organic material.

Care of eggs is the most common parental care behavior reported for intertidal fishes, which asserts normal growth and development, and gives protection against predation (Keenleyside, 1979; Coleman, 1999). Mouthing and fanning were never reported for Gobiesocidae fishes in the wild, and they are probably more related to nest cleaning than to oxygenation, since the shallowest intertidal zone has a high hydrodynamic stress that provides ventilation. An additional indication that mouthing and fanning are more related to nest cleaning than ventilation is that the intense yolk coloration is probably due to the presence of carotenoids that facilitate oxygen transport during respiration (Fishelson, 1976; Balon, 1977).

The courtship behavior and parental care described herein were based on a single event, and we decided to keep the fish alive in the wild and observe their behavior as much as

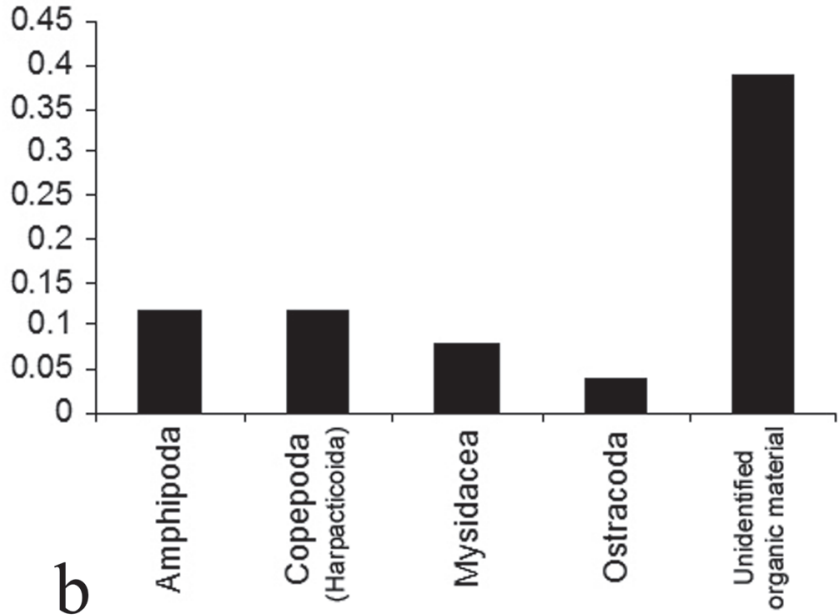

possible, instead of collecting them for sex determination in the laboratory. Based on the literature regarding other Gobiesocidae species (e.g., Runyan, 1961; Coleman, 1999), it is likely that the "guardian" is a male (see Figueiredo \& Menezes, 1978; Carvalho-Filho, 1999).

The nest characteristics herein found for G. barbatulus are similar to those of all intertidal fishes (DeMartini, 1999). The spherical form of the eggs may be an adaptation that reduces the area/volume relationship and helps preventing against drying while they stay emerged (DeMartini, 1999). Gobiesox barbatulus, as observed herein, as well as in other intertidal fishes, can tolerate some time outside the water as long as they are kept wet (Coleman, 1999).

The mating behavior reported herein is unique in the literature about Gobiesocidae fishes in the wild. The absence
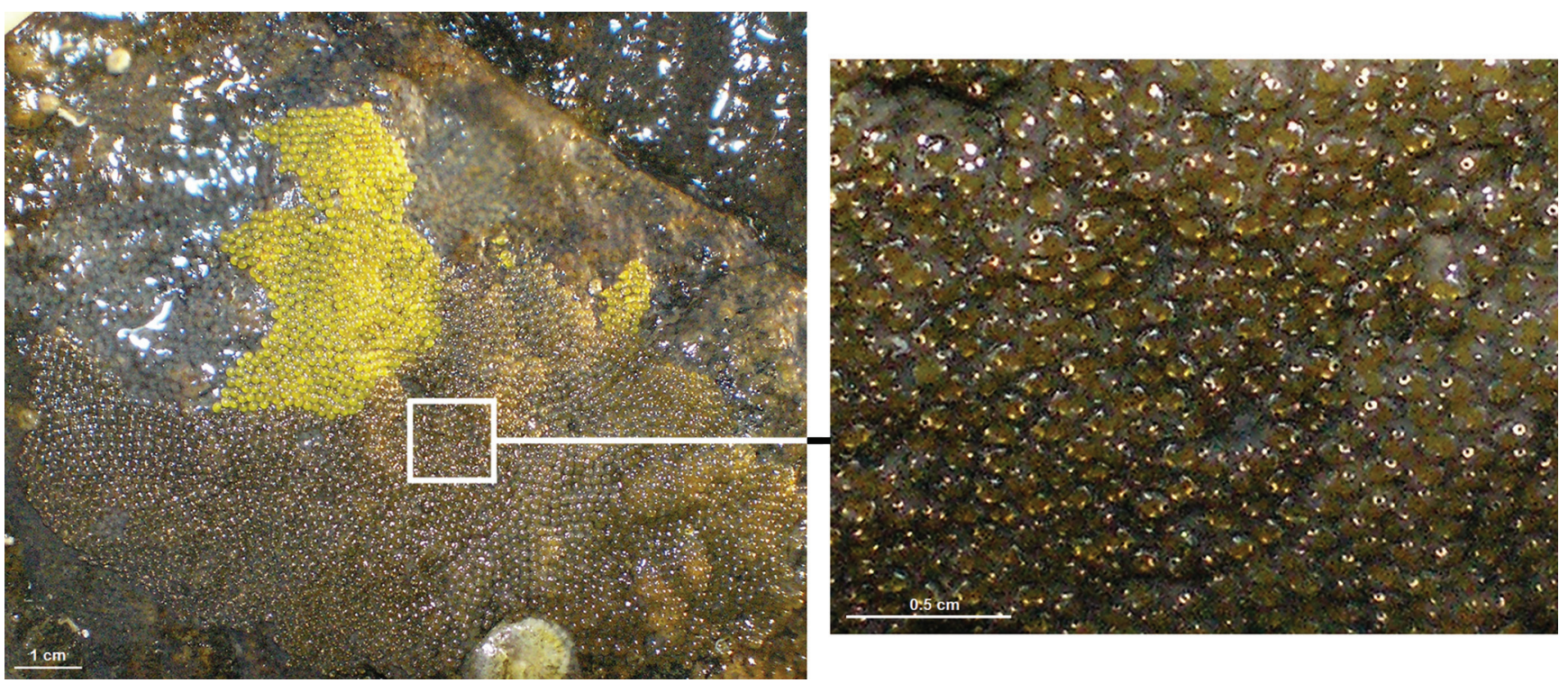

Fig. 5. Eggs of Gobiesox barbatulus. The bright reflective substance in the upper left side is composed of remains of the adhesive substance from eggs already ecloded. The yellow part is composed of eggs with intense yolk coloration. On the right side a detail shows juvenile fishes ready to eclode. 

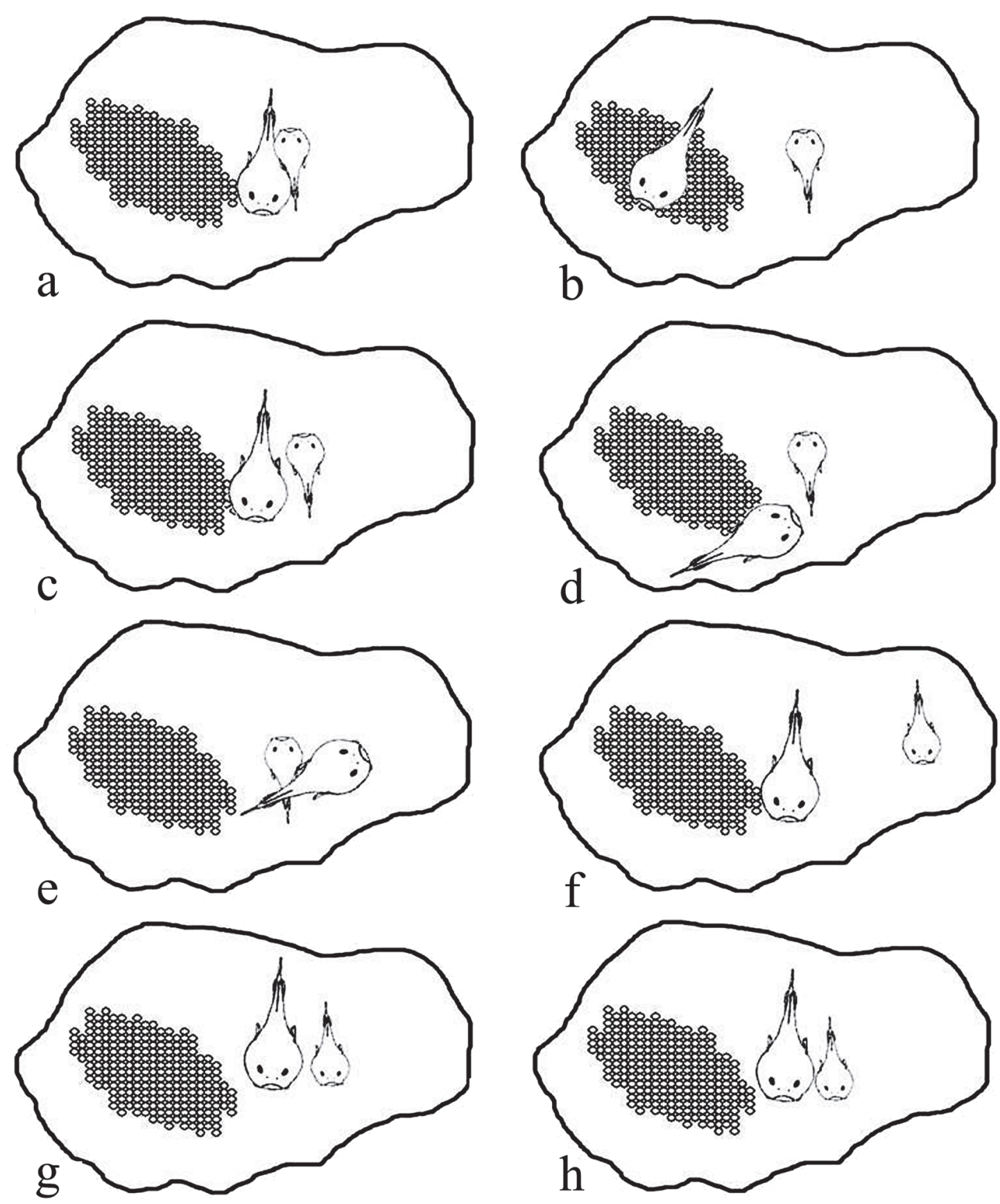

Fig. 6. Courtship movements recorded for a pair of Gobiesox barbatulus in the wild. Each cycle did not exceed 30 min of duration, and always started with one of the three "pre-mating" positions [i.e., (a, e, and $\mathbf{h})]$. After mating the pair did not stay in contact (b or f), and the larger individual performed parental behavior (b). They restarted the cycle after moving to a spot without eggs, following new approximation $(\mathbf{c}, \mathbf{d}$, and $\mathbf{g}$ ). It is important to note that there are many sequences possible based in such events, since they can alternate.

of such data is probably related to characteristics of the environment these fishes inhabit, the very low depth of the habitats and their cryptic life under stones being probably the worst limitations, making underwater observations difficult (Marliave \& DeMartini, 1977). The diurnal spawning is in accordance with what is expected for this species based on the literature (e.g., DeMartini, 1999) and may be a strategy to avoid egg predation by nocturnal predators such as crustaceans.
The nests containing eggs at different developmental stages suggest that the same individual performs several courting acts during the same reproductive season (Fig. 5).

The findings presented herein indicate that G. barbatulus displays shelter fidelity, being probably territorial; a characteristic shared by many intertidal fishes including its congener, the northern clingfish G. maeandricus (Abel, 1962; Gibson, 1967, 1982). Further studies may better focus on 
territoriality and/or abundance of G. barbatulus in the wild, this study being only the first step to better understand this poorly known species.

\section{Acknowledgements}

We would like to thank Tagea K. S. Björnberg for help with stomach content identification; Nicholas J. Totten and Samantha M. Esteves for useful suggestions on the manuscript and English revision; Rodrigo A. S. Pereira and Ricardo M. C. Castro for comments and useful suggestions; Flávio A. Bockmann at LIRP, CEBIMar and FFCLRP-USP for academical and logistical support; IBAMA for the collection permit; FAPESP (grants 05/51856-6 and 05/51855-0) to FZG, for essential financial support.

\section{Literature Cited}

Abel, E. 1962. Freiwasserbeobachtungen an Fischen im Golf von Neapel als Beitrag zur Kenntnis ihrer Ökologie und ihres Verhaltens. Internationale Revue der gesamten Hydrobiologie und Hydrographie, 47: 219-290.

Alexander, R. M. 1967. Functional design in fishes. London, Hutchinson University Library, 160p.

Altmann, J. 1974. Observational study of behavior: sampling methods. Behavior, 49: 227-265.

Balon, E. K. 1977. Early ontogeny of Labeotropheus Ahl 1927 (Mbuna, Cichlidae, Lake Malawi), with discussion on advanced protective styles in fish reproduction and development. Environmental Biology of Fishes, 2: 147-176.

Barreiros, J. P., A. Bertoncini, L. Machado, M. Hostim-Silva \& R. S. Santos. 2004. Diversity and seasonal chances in the ichthyofauna of rocky tidal pools from Praia Vermelha and São Roque, Santa Catarina. Brazilian Archives of Biology and Technology, 47: 291-299.

Bennett, B., C. L. Griffiths \& M. Penrith. 1983. The diets of littoral fish from the Cape Peninsula. South African Journal of Zoology, 18: 343-352.

Bowen, S. H. 1992. Quantitative description of the diet. Pp. 325336. In: Nielson, L. A. \& D. L. Johnson (Eds.). Fisheries Techniques. Blacksburg, American Fisheries Society, 468p.

Bye, V. J. 1984. The role of environmental factors in the timing of reproductive cycles. Pp. 187-205. In: Potts, G. W. \& R. J. Wootton (Eds.). Fish Reproduction: Strategies and Tactics. London, Academic Press, 410p.

Carvalho-Filho, A. 1999. Peixes: costa brasileira, $3^{\mathrm{a}}$ ed. São Paulo, Editora Melro, 320p.

Chotkowski, M. A. 1999. Systematics of intertidal fishes. Pp. 297-331. In: Horn, M. H., K. L. M. Martin, \& M. A. Chotkowski (Eds.). Intertidal Fishes: Life in Two Worlds. San Diego, Academic Press, 399p.

Coleman, R. M. 1999. Parental care in intertidal fishes. Pp. 165180. In: Horn, M. H., K. L. M. Martin, \& M. A. Chotkowski (Eds). Intertidal Fishes: Life in Two Worlds. San Diego, Academic Press, 399p.

DeMartini, E. E. 1999. Intertidal spawning. Pp. 143-164. In: Horn, M. H., K. L. M. Martin, \& M. A. Chotkowski (Eds). Intertidal Fishes: Life in Two Worlds. San Diego, Academic Press, 399p.

Figueiredo, J. L. \& N. A. Menezes. 1978. Manual de peixes marinhos do sudeste do Brasil. II. Teleostei (1). São Paulo, MZUSP, 110p.
Fishelson, L. 1976. Spawning and larval development of the blenniid fish Meiacanthus nigrolineatus from the Red Sea. Copeia, 1976: 798-800.

Froese, R. \& D. Pauly. Editors. 2008. FishBase. World Wide Web electronic publication. www.fishbase.org, version (11/2008).

Gibson, R. N. 1967. Studies on the movements of littoral fish. Journal of Animal Ecology, 36: 215-234.

Gibson, R. N. 1969. The biology and behaviour of littoral fish. Oceanography and Marine Biology Annual Review, 7: 367-410.

Gibson, R. N. 1982. Recent studies on the biology of intertidal fishes. Oceanography and Marine Biology Annual Review, 20: 363-414.

Grossman, G. D. 1986. Food resource partitioning in a rock intertidal fish assemblage. Journal of Zoology, 1: 317-355.

Helfman, G. S. 1983. Underwater methods. Pp. 349-369. In: Nielson, L. A. \& D. L. Johnson (Eds). Fisheries Techniques. Blacksburg, American Fisheries Society, 468p.

Hofrichter, R. \& R. A. Patzner. 2000. Habitat and microhabitat of Mediterranean clingfishes (Teleostei: Gobiesociformes: Gobiesocidae). Marine Ecology, 21(1): 41-53.

Hynes, H. B. N. 1950. The food of fresh-water sticklebacks (Gasterosteus aculeatus and Pygosteus pungitius), with a review of methods used in studies of the food of fishes. Journal of Animal Ecology, 19: 36-57.

Johnson, C. R. 1970. Notes on the intertidal life history of the Northern clingfish, Gobiesox maeandricus (Girard). American Midland Naturalist, 83(2): 625-627.

Johnson, R. K. \& D. W. Greenfield. 1983. Clingfishes (Gobiesocidae) from Belize and Honduras, Central America, with a redescription of Gobiesox barbatulus Starks. Northeast Gulf Science, 6: 33-49.

Keenleyside, M. H. A. 1979. Diversity and adaptation in fish behaviour. Berlin, Springer-Verlag, 208p.

Marliave, J. B. \& E. E. DeMartini. 1977. Parental behaviour of intertidal fishes of the stichaeid genus Xiphister. Canadian Journal of Zoology, 55: 60-63.

Menezes, N. A. 2003. Gobiesocidae. Pp. 96-97. In: Menezes, N. A., P. A. Buckup, J. L. Figueiredo \& R. L. Moura (Eds.). Catálogo das Espécies de Peixes Marinhos do Brasil. São Paulo, Museu de Zoologia da Universidade de São Paulo, 159p.

Nelson, J. S. 2006. Fishes of the world. $4^{\text {th }}$ Ed. Hoboken, John Wiley \& Sons, Inc., 601p.

Norton, S. F. \& A. E. Cook. 1999. Systematics of intertidal fishes. Pp. 223-263. In: Horn, M. H., K. L. M. Martin, \& M. A. Chotkowski (Eds). Intertidal Fishes: Life in Two Worlds. San Diego, Academic Press, 399p.

Prochazka, K., M. A. Chotkowski \& D. G. Buth. 1999. Biogeography of rocky intertidal fishes. Pp. 332-355. In: Horn, M. H., K. L. M. Martin, \& M. A. Chotkowski (Eds.). Intertidal Fishes: Life in Two Worlds. San Diego, Academic Press, 399p.

Runyan, S. 1961. Early development of the clingfish, Gobiesox strumosus Cope. Chesapeake Science, 2: 113-141.

Sampaio, C. L. S., J. A. C. C. Nunes \& L. F. Mender. 2004. Acyrtus pauciradiatus, a new species of clingfish (Teleostei: Gobiesocidae) from Fernando de Noronha Archipelago, Pernambuco state, Northeastern Brazil. Neotropical Ichthyology, 4: 206-208.

Sazima, I. 1986. Similarities in feeding behaviour between some marine and freshwater fishes in two tropical communities. Journal of Fish Biology, 29: 53-65.

Varas, E. \& F. P. Ojeda. 1990. Intertidal fish assemblages of central Chilean coast: Diversity, abundance and trophic patterns. Revista de Biologia Marina y Oceanografia, 25: 59-70.

Accepted October 10, 2010

Published March 31, 2011 